\begin{tabular}{|c|c|c|}
\hline $\begin{array}{l}\text { FATIH } \\
\text { SULTAN } \\
\text { MEHMET } \\
\text { VAKIF UNIVERSITESI } \\
2010\end{array}$ & $\begin{array}{l}\text { FSM İlmî Araştırmalar Insan ve Toplum Bilimleri Dergisi } \\
\text { =SM Scholarly Studies Journal of Humanities and Social Sciences } \\
\text { Sayı/Number } 13 \text { Yıl/Year } 2019 \text { Bahar/Spring } \\
\text { (C)2019 Fatih Sultan Mehmet Vakıf Üniversitesi }\end{array}$ & 口iring \\
\hline DOI: 10.16947/fsmia.582426 & http://dergipark.org.tr/fsmia & http://dergi.fsm.edu.tr \\
\hline Araştırma Makalesi / Research Article & Geliş Tarihi / Received: 01.05.2019 Kabul Tarihi / Accepted: 19.06.2019 & FSMIAD, 2019; (13): 335-356 \\
\hline
\end{tabular}

\title{
Anadolu Gotiği: Korku Romanındaki Evrimin Son Durağı
}

Veli Uğur

\section{$\ddot{O} z$}

Gotik edebiyat ilk olarak Avrupa'da ortaya çıkmıştır. Dolayısıyla bu kıtanın tarihi özelliklerini yansıtmaktadır. Aristokrat geçmişin otoriter ayrımları gotik edebiyatın en önemli belirleyenidir. Ayrıca modernizmi savunan ve karşı çıkan alt türleriyle kuramsal bir tavır da barındırmaktadır. Bu edebi tür Amerika'ya götürüldüğünde yeni kıtanın sosyal, tarihi, ekonomik yanlarının etkisinde kalmıştır.

Amerikan gotiğinde söz konusu ülkenin coğrafi özellikleri yansıtılmıştır. Benzer şekilde Anadolu gotiği de yerli coğrafyanın özelliklerini barındırmaktadır. Geçmişten gelen halk kültürün içindeki korku ögeleri yeni dönem romanlarına aktarılmaya başlanmıştır. Böylece Anadolu'nun insanı ve coğrafyası korku romanlarının konusu olmuştur.

Anahtar Kelimeler: Gotik, Anadolu gotiği, korku romanları, Amerikan gotik romanı.

* Dr. Öğr. Üyesi, Muğla Sıtkı Koçman Üniversitesi Edebiyat Fakültesi Türk Dili ve Edebiyatı Bölümü, Muğla/Türkiye, vugur24@gmail.com, orcid.org/0000-0003-3832-5620 


\title{
Anatolian Gothic: The Final Stand of Evolution in Horror Novel
}

\begin{abstract}
Gothic literature first appeared in Europe. Therefore, it reflects the historical features of this continent. The authoritarian distinctions of the aristocratic past are the most important determinants of gothic literature. It also has a theoretical attitude with its sub-genres defending and opposing modernism. This literary genre is taken to America and has been influenced by the social, historical and economic aspects of the new continent.

In the American gothic, the geographical features of the country were reflected. Similarly, Anatolian gothic include the characteristics of the native geography. The elements of fear in the folk culture from the past began to be transferred to the novels of the new era. Thus, the people and geography of Anatolia became the subject of horror novels.
\end{abstract}

Keywords: Gothic, Anatolian gothic, horror fiction, American gothic novel. 


\section{Giriş}

Romanımızın her geçen gün yeni türler ve bunlara bağlı alt türlerle tanıştı̆g1na şahit olmaktayız. Örneğin ilk olarak 1990'lı yıllarda ürünlerine rastladığımız fantastik edebiyat bugün şehir fantezisi, kılıç ve büyü gibi alt türlere ayrılmış durumdadır. Tarihi roman adını verdiğimiz genel kategori ise yakın dönemde tarihi fantezi adını verdiğimiz yeni bir alt tür kazanmıştır. Benzer bir gelişme korku edebiyatında da görülmüştür. Örneğin Batı edebiyatında bir alt tür olan "lanetli ev", "zombi" gibi başlıklar yerli korku edebiyatımızda kendilerine yer bulmaya başlamıştır. Daha önceleri de doğaüstü ve gerçeklikten kaynaklanan korku çok sayıda alt türe giren romanlarla işlenmiş ve çeşitlenmiştir. Dolayısıyla korku edebiyatımız Ahmet Mithat Efendi'nin Cinli Han'ından beri önemli bir yol kat etmiştir.

Korku edebiyatı kendi seyrinde devam ederken günümüzde yeni bir alt türe kavuşmuştur. "Anadolu gotiği”" adını verebileceğimiz bu alt tür hem önceki alt türlerin birçok özelliğini taşımakta hem de kendine has orijinal yenilikler içermektedir. Örneğin yamyamlık, hayalet, cadılık gibi alt tür unsurları burada da karşımıza çıkmaktadır ancak tamamen yeni bir atmosferin ürünü olarak. Andığımız bu atmosfer makalemizin konusunu oluşturacak, Anadolu gotiğini şekillendiren ortam ele alınarak türün kendine has özellikleri belirlenmeye çalış1lacaktır. Ancak öncelikle alt türün isminin belirlenmesine esin kaynağı olan Amerikan gotiğinden bahsedilecektir. Ardından bu alt türün Amerikan gotiğine benzer yanları bir başka deyişle önceki alt türlerden farkları örneklerle ortaya konulmaya çalışılacaktır.

\section{Amerikan ve Anadolu Gotik Yazınlarının Özellikleri}

Avrupa'da başlayan gotik edebiyat düşünüldüğünde akla ilk gelen imajlar şatolar, dehlizler, mahzenler, aristokrasi, işkenceler ve karanlık atmosferdir. Bu edebi türün alt yapısında soylu sınıf ile köylüler arasındaki gerilim, eski kavimlerin yarattı̆g 1 dehşet ve modernizme yönelik tepkiler geniş yer tutar. Dolayısıyla Avrupa tarihi ve sınıfsal yapısı gotik edebiyatın temel belirleyenleridir. Bu tür, Amerika'ya gittiğinde ise bazı temel değişikliklere uğrar. En önemli değişikliklerden biri mimari yapılardadır. Avrupa'nın geçmişinden gelen şatolar modern olanla tanışıklığ çok daha yeni olan Amerika'da yoktur. Mekânsal anlamda ortaya çıkan boşluk Amerika' da malikâneler ve eski zamanlarda yapılmış evlerle doldurulur. Avrupa'daki aristokrat geçmişin yerini de malikânenin sahibi olan ailenin geçmişten gelen kaygıları ve korkuları alır. Aile mülkündeki efsanevi bir hayalet, bilinmeyen bir oluşum veya dehşetli bir ölüm hikâyesi yani geçmişin bastırılmış, unutulmuş, 
unutulmak istenen unsurlarının geri dönüşü Amerikan gotiğinin en önemli parçalarındandir ${ }^{1}$

Amerikan gotiğinin diğer önemli parçası coğrafyadır. Avrupalıların yeni taşındıkları bu kara parçasının sınırları, ıssızlığın hâkim olduğu, insanın doğadan gelebilecek tehlikelere karşı savunma imkânlarının yetersiz kaldığı yerlerdir. Sonsuz görünen bu topraklardaki ormanlar ise yabaniliğin en somut mekânıdır. Avrupa'daki ormanlar efsanevi canavarların mekânı iken Amerika'dakiler bilinmeyen korkutucu, ölümcül canlılarla doludur. ${ }^{2}$ Orman olmayan yerlerde de benzer bir tehlike vardır. Arazi manzaraları dağların, kayalıkların, çorak arazilerin korunaksız, zâlim ve acımasız doğası üzerine kuruludur. ${ }^{3}$

Kızılderililer Amerika'ya giden göçmenlerin korkulu rüyalarından olmuş bu nedenle edebiyatta da karşılık bulmuşlardır. Ancak bu yansıma öncelikle, ilk sömürgecilerin yerliler hakkındaki yamyamlık suçlamasını, sonrasında ise göçmenlerle yerliler arasında gerçekleşen çatışmaları referans almıştır. $\mathrm{Bu}$ sırada karşılıklı gerçekleşen vahşet gotik edebiyatın konularından biri olmuştur. Gotik edebiyat burada eleştirici bir tavır takınmış ve kimin vahşi olduğunu sorgulamıştır. ${ }^{4}$ Yerli korkusu ve yabancı saldırganlığ gotik edebiyatın insanın derinlerde yatan korkularını hatırlatmak için verimli iki kaynak haline gelmiştir.

Benzer biçimde Amerika'nın kuruluşunu sağlayan en önemli fiziksel güç olan kölelerin yaşamı da gotik edebiyatın beslendiği alanlardandır. Kölelik psikolojik ve sosyal kimi güçlerin uyguladığı baskıyı tasvir etmek için metafor olarak ya da kölelerin maruz kaldığı somut baskıyı göstermek için gerçekçi biçimlerde kullanılmıştır. ${ }^{5}$

Amerikan gotik edebiyatı Amerika'nın püriten geçmişinden, Avrupa'daki demokrasi fikrinin yarattığı gerilimlerden ve yeni keşfedilmiş topraklardaki geri kalmışlık gibi dışsal başka durumlardan da etkilenmiştir. Ancak bunlar kadar önemli olan bir başka boyutu insanın iç dünyasına yönelmesidir. Böylece gotik, sadece dışa bağımlı bir tür olmaktan kurtulur ve modern korku edebiyatının ön-

1 Eric Savoy - Robert K. Martin (haz.), American Gothic: New Intervations in a National Narrative, Iowa, University of Iowa Press, 1998, s. 9.

2 Glenn Turner, "The Branching of 19th Century American Gothic Literature From Its European Roots” , t.y. http://forumonpublicpolicy.com/wp-content/uploads/2016/12/Turner.pdf s. 8.

3 Allan Lloyd Smith, American Gothic Fiction: An Introduction, New York, London, Continuum International Publishing, 2005. s. 7.

4 Joel Faflak - Jason William Haslam, (haz.), American Gothic Culture: An Edinburg Companion Ed., Edinburg, Edinburgh University Press, 2018, s.30

5 A.g.e., s. 45. 
cüsü haline gelir. Özellikle "Edgar Allan Poe ile birlikte psikolojik boyut gotiğin önemli bir parçası olur. Suçlu, saplantıl1, akli dengesi bozuk insanların psikolojilerini yansıttı̆̆ dengesizliği korku ve dehşet duygularını tetiklemektedir."”

Yukarıda genel özelliklerini sıraladığımız Amerikan gotiğini genel olarak değerlendirdiğimizde “özgülük”le karşılaşırız. Gotik edebiyat Avrupa'dan çıkıp okyanusu aşmış Amerika'ya gitmiş̧ir. Ancak burada değişmiş, yeni topraklara özgü bir içeriğe bürünmüştür. Yeni Dünya'nın toplumsal ve siyasal yapısı, çevre koşulları, toplumsal inşa biçimi Avrupa'dan getirilen edebi gelenekleri yeniden şekillendirerek kendine has bir hale getirmiştir.

Gotik edebiyatın Anadolu macerasında da benzer bir durum söz konusudur. Ancak bu sürecin ayrıntılarına girmeden, yerli korku edebiyatının önceki dönemine dair birkaç söz söylemek gerekmektedir. 1990'l1 y1llara kadar olan yerli korku romanları incelendiğinde Batı'nın büyük etkisi görülür. Korku romanının genel figürleri, mekânları ve konuları önce Batı'da belirlendiği için Türk edebiyatındaki örneklerinin de bunlara öykündüğünü söylemek abartı olmaz. Örneğin Melek Melih Bayrı'nın Vampir'in Kamburu, Daniş Remzi Korok'un Ölü Ciğeri Yiyen Adam, Ölü Ciğeri Nasıl Yenir?, Ali Rıza Seyfi'nin Kazıklı Voyvoda, Nazmi Erman'ın Frankenstein gibi romanlarına bakıldığında yamyamlık, vampir, yaratık konularının işlendiği görülür. Bunların hepsinin Batılı korku romanlarından esinlendiği açıktır. M. Fahrettin Pakkan'ın Vahşi Fırtına ve Vahşet, Bedii Vecdet'in Afrika Vahşileri Arasında Bir Türk Gencinin Hatıratı gibi romanların da Avrupa'da yazılan ve egzotik diyarlarda geçen macera romanlarını örnek aldığı hemen anlaşılmaktadır. Burada tek tek ele almanın mümkün olmadığı bu romanlarda İstanbul'un ya da uzak ülkelerin asıl mekân olduğu görülür. Bir kısmına uzun hikâye diyebileceğimiz bu eserlerde her yanıyla İstanbul'un merkezde olması Batılı olanlara benzer eserler yazılmasını kolaylaştırmıştır. Dolayısıyla bu metinlerde yerli kültür ve coğrafyayı, Anadolu insanının yaşam biçimini bulmak neredeyse imkânsızdır. Batılı tarzda yaşayan, yabancı dil bilen, Batı'dan gelen korku figürleriyle mücadele eden kişilerin öyküleri orijinal olsa bile adaptasyon havasından kurtulamamış ve yerli, Anadolu'ya özgü bir korku edebiyatı yaratılamamıştır.

Son yirmi yıllık döneme baktığımızda ise durumun değişmeye başladığı görülür. Korku edebiyatımızın Batı'yı taklit eden ya da tekrarlayan görünümden kurtulmasını sağlayan en önemli etken yerel kültürle ve coğrafyayla kurulan bağlantılardır. Korku edebiyatı geliştikçe yabancı figürlerin yerini yerlilerin

6 Çiğdem Pala Mull, Gotik Romanın Kıtalararası Serüveni, Ankara, Ürün Yayınları, 2008, s. 112. 
almaya başlaması kaçınılmazdır. Cinler, cadılar, alkarısı gibi yaygın, kültürel alanda yerleşik korku figürlerinin romanlarda görünmesi şaşırtıcı değildir. Ancak Anadolu'nun 1ssız topraklarının korku kaynağı haline gelmesi bundan çok daha önemli bir gelişmedir. Uçsuz bucaksız bozkırın, ormanların, yaylaların kapladığı Anadolu tek başına insanın korkuyu derinden yaşamasına müsâit bir coğrafyadır. Dolayısıyla hiçbir kültürel geçmişe dayanmadan doğrudan bu coğrafyanın kendisinin yaratacağı korkuya odaklanmak bile sözünü ettiğimiz yeni alt türün olgunlaşmasına katkıda bulunacaktır. Kısacası Anadolu gotiğini ayırt eden en temel hususlar Anadolu'ya ait coğrafî isimlerin, yer şekillerinin, hayvanların, 1ssız yerlerdeki toplum birimlerinin ve geleneksel inanışların korku kaynağ 1 haline gelmesidir. Konunun daha iyi anlaşılması için Anadolu gotiğinin tespit edebildiğimiz özelliklerini ele almak gerekmektedir. Burada, yerli roman ve hikâyelerden verilecek örneklerin tek olmadığını, çok sayıda eserde görüldüğünü belirtmekte fayda vardır. Yani örneğin alkarısı figürü tek bir eserde değil farklı metinlerde karşımıza çıkmaktadır. Ancak makalenin tekrarlara düşmemesi ve eser isimlerine boğulmaması için tekil örneklerle yetinilmiştir.

\section{Anadolu Gotiğinin Eserlerdeki Formülasyonu}

Anadolu'yu merkeze alan gotik edebiyat ürünlerine bakıldığında aralarında bazı benzerlikler olduğu görülür. Yukarıda değindiğimiz genel başlıkların yanında, konunun ilerleyiş aşamaları, mekânların seçimi, metinlere dâhil olan kişilerin özellikleri, insan dışı varlıklar, yerel kültürden kaynaklanan inanç ve yaşam biçimleri birbirine benzemektedir. Ancak bu durum birbirinin kopyası eserlerin kaleme alındığ 1 anlamına gelmemelidir. Tam tersine değindiğimiz başlıkların içeriklerinin zenginliği orijinalliğin yolunu açmaktadır. Aşağıdaki başlıkların içerikleri eserlerin, hangi güzergahlarda ilerlediğini ve kurgunun nasıl şekillendiğini göstermektedir.

\section{A- Anadolu'ya gidiş:}

\section{1- Mekân}

Anadolu gotiği türündeki eserlerin en önemli özelliklerinden biri mekânın eski korku romanlarında çok yer tutan İstanbul'un dışına çıkmasıdır. Anadolu'daki çok sayıda şehir korku atmosferinin yaratılması için uygun ortam sağlamaktadır. Trabzon, Artvin, Giresun, Kırklareli, Konya vb. İstanbul'dan çok uzak yerlerdeki şehirler, geleneklerin ve eskiden kalma inançların yaşamaya devam ettiği yerlerdir. Roman ve öykülerde taşra şehirlerinin ve özellikle de köylerin odağa alınmasının nedeni yalıtılmışlık duygusunun yoğunluklu olarak verilebileceği yerler olmalarıdır. Dışarıdan köye giden bir kişinin sıra dışı bir durumla karşılaştı̆̆ında 
sığınabileceği başka bir yer yoktur. Yalıtılmış ortam çaresizliği beraberinde getirmekte, kötülükle, korkutucu olanla yüzleşmeyi kaçınılmaz kılmaktadır. Örneğin Erol Çelik'in, Ağlatan adlı romanına mekân olarak seçtiği Nevşehir'in Çorak11 köyü yalıtılmışlığın yol açtığı sorunları çizebilmek açısından iyi bir tercihtir. Köy, adından da anlaşılacağı gibi aslında çorak bir yerdir. Ancak uzun yıllar önce, denizi olmayan köye bir deniz feneri inşa edilmiş ve toprak bir anda çok verimli bir yere dönüşmüştür. Fenere yerleşen bir cadı ise köylüleri etkisi altına almıştır. Onunla iyi geçinmeyen insanlar öldürülmekte; o, feneri yakmadığı gecelerde köyde çocuklar öldürülmektedir. Köylüler mecburen onun hâkimiyetini kabullenmiştir. Romanın sonunda ise cadının başlattığı olaylar tam bir katliama dönüşür ve yirmiden fazla insan öldürülür. Romanda, köyün çevreye uzaklığı ve yalıtılmışlığının cadının hâkimiyetine etkisi özellikle vurgulanır. Gazeteci Mehmet'in uzun süre bozkırda araba sürmesi ve yolunu kaybetmesi yerleşim yerlerinden uzaklaşarak ıssızlığın ortasına varmasına neden olur. Tek sığınacağı yer ise Çoraklı köyüdür. Köyün içine kapanık yaşantısında yabancılara yer yoktur. Bu nedenle Mehmet ilk andan itibaren kendisini tehdit olarak gören cadi ve onun kontrol ettiği köylüler tarafından "istenmeyen yabancı" ilan edilir. Köylüler yabancı olan, kendilerine ait olmayan her şeyden uzak durmaktadır. Köyde barındığı handakiler ona iyi davranmamış hatta bir an önce gitmesi için uyarmışlardır. Köyün ıssızlığın ortasında olmasından kaynaklanan gerilim, nüfusun kozmopolit olmayan, homojen yapısı ile daha da artar. Yabancının kendisi de istenmediğini çeşitli biçimlerde anlayarak ait olmadığı topraklardan bir an önce ayrılmak ister. Ancak çeşitli talihsizlikler ve gazeteci merakı onun uzaklaşmasını engelleyerek dehşetle karşılaşmasına neden olur.

Anadolu Korku Öyküleri adlı üç kitaptan oluşan seride de farklı yazarların kaleminden, Anadolu' da yalıtılmış köy ortamlarına giren yabancıların karşılaştıkları korkutucu olaylar anlatılmıştır. ${ }^{7}$ Serinin ikinci kitabındaki Zifir Karanın Mavisi adlı hikâyede yapılan tasvir anlatıcının köye girdiği ilk anda yaşadığı gerilimi de yansitir niteliktedir:

"Dahası bu ev yer yer sıvaları sıyrılmış, yamalı duvarlarından sızan, mezar gibi kokmasına sebep olan o tuhaf küflü toprak kokusu ile Ekin'e tam manasıyla ölümü çağrıştırıyordu. ... Bir tek ev değildi problem; köy de tıpkı bu evin bir yansıması gibiydi. Aynı ağır eskimişlik kokusu asılı kalmıştı havasında. Tozluydu, küflüydü, ölmüş de zorla diriltilmiş gibiydi. Köyün ahalisi de garipti. Nefes

7 Anadolu coğrafyasının korku için merkeze alındığı bu türden bir serinin yayımlanması bile makalede bahsettiğimiz türün gelişimi açısından umut vericidir. 
alıyorlar, konuşuyorlar, yiyorlar, içiyorlar, çalışıyorlar, uyuyorlardı ama tüm bunları sanki görünmez birinden direktif alır gibi yapıyorlard1. Ne bir duygu belirtisi, ne bir refleks, ne de bir tepki vardı. Bir insanın yaşıyor olduğunun en büyük kanıtı olan gözlerdeki o 1şı yoktu."

İlk anda sıradan görünen köy ve halkı, yakından bakıldığında tekinsiz bir ortam oluşturmaktadır. Hem görünüş hem de davranışlar insan sıcağını yansıtmamaktadır. Diğer korku anlatılarında olduğu gibi buradaki toplumsal birim de Anadolu'nun genelinde paylaşılan kültürden ayrılmış, yaygın olmayan kültürel davranış, düşünüş ve inanç biçimlerini yaşayan küçük insan grubudur. Mekânla bu grubun birlikteliği tamamlayıcı olmakta, korku edebiyatının boyutlarını genişletmektedir.

Kısacası geniş coğrafyanın, bozkır, orman ya da dağ gibi doğal engellerle yalıtılmış olan bir parçasındaki köy içine kapanan, yabancıları dışlayan, kendine has batıl inançlar ve yaşam biçimi geliştiren yanlarıyla korku için elverişli bir ortam olmaktadır.

\section{2- Coğrafya ve Doğa}

Anadolu gotiğine dâhil edebileceğimiz anlatılarda coğrafî̀ ve doğal ortam köyün yalıtılmasına neden olmaktadır. Ancak bunun kadar önemli bir başka mesele de coğrafya ve doğanın kendilerinin de korkunun kaynaklarından birine dönüşebilmeleridir. Amerikan gotiğinde sınır hatlarındaki, medeniyetten uzak yerlerin yarattığ 1 korkunun bir benzeri burada karşımıza çıkar. Anadolu' daki geniş, insansız bozkırlar, göz alabildiğine uzanan ovalar, mağaralar ve dağlar kendiliğinden, tekinsizlik duygusunu oluşturma potansiyeli olan yerlerdir. Gerçek hayatta, böyle ortamlarda, insanın tek başınalığı hissedebilme ve korkuya kapılma ihtimali metinlerde de inandırıcı bir etki yaratılmasına yardım etmektedir.

Çağan Dikenelli’nin kaleme aldığı Taşsıyıcı romanı uzayıp giden bozkırın tekinsizlik duygusu veren bilinmeyelerini konu edinmektedir. Oğuz adlı arkeolog Orta Anadolu'da, bozkırın ortasında bir kaza sonucu tesadüfen eski bir medeniyetin izlerini bulur. $\mathrm{O}$ ve arkadaşlarının araştırma için bölgeye gelmelerinden itibaren ölümlerle sonuçlanan olaylar dizisi başlar. Romanda bozkır ile birlikte bahsedilen medeniyete ait izlerin bulunduğu mağara, kayalıklar, tünel, büyücü kadın ve dehşetli ölüm sahneleri korku duygusunun bütünleşmesine yardımc1 olurlar. Anadolu'nun nüfusu sürekli artmasına rağmen bozkırın keşfedilmemiş

8 Işın Beril Tetik, "Zifir Karanın Mavisi”, Anadolu Korku Öyküleri 2, 2. bs., Ankara, Bilgi Yay1nevi, 2017, s. 13. 
binlerce sırrı vardır. Bu sırlar diğer doğal oluşumlarla ve kimi doğaüstü güçlerle birleştiğinde tedirginlik, gerilim ve korku yaratan bir yere dönüşmektedir.

Orhan Yıldırım'ın yazdığı Çoruh Seni Lanetliyor ve Ecinni adlı romanların ise Karadeniz'in ormanlarla kaplı yapısı öne çıkar. Yörede, genelde kapalı olan hava ile çok s1k ormanlar birleşince gündüz bile loş bir ortam yaratmaktadır. Buna gece karanlığı eklendiğinde ormanın çeşitli sesleri ve hayvanlar korku duygusunu beslemektedir. Böyle bir ortam Ecinni romanındaki gibi cinlerle ilgili hikâyelerin ya da Çoruh Seni Lanetliyor'daki seri cinayetlerin yarattı̆̆ dehşet duygusunu yoğunlaştırmaktadır. Zevk alınabilecek bir yer olan doğa en tehlikeli maceraların yaşandığı bir ortam da olabilmektedir.

Doğal yapıların yanında iklim koşulları da sıra dışı ölüm korkusunun yoğun yaşanmasını sağlayan etkenlerdir. Eserlerde özellikle kar ve firtına insan gücünün sınırlarını aşan engeller yaratarak çaresizlik, umutsuzluk ve bitmişlik duyguları yaratırlar. Bunlara vahşi hayvanlar, özellikle de Anadolu bozkırının vazgeçilmezi olan kurtlar eklendiğinde insan iradesi ve fiziksel gücünün test edildiği bir ortam oluşur. Aydın Şahin Öztürk'ün yazdığı Beyaz Çöl romanı ile Ayfer Tunç'un Kar Yolcusu adlı hikâyelerinde kar, firtına ve kurtlar üçlüsünün insana yaşatabilecekleri anlatılmaktadır. Beyaz Çöl adından da anlaşıldığı gibi tüm coğrafyanın karla kaplı olduğu bir ortamda köylülerin kurtlara karşı verdikleri mücadeleyi konu edinmektedir. Ancak düşman sıradan kurtlarla sınırlı değildir. Doğaüstü güçlerce büyütülmüş olan devasa boyutta ve güçteki bir kurt da köye musallat olmuştur. Dev kurdun kendisine tuzak kurmak için verilen bir köylünün cesedini parçalamasından sonraki manzara şöyle tasvir edilir:

"Cemal'in kanları, yağları, çeşitli organlarının biçimsiz ve donmuş parçaları, kıl ve pislik kalıntıları, yerlere, duvarlara, her yere sıçramıştı. Ağır leş kokusu genzini yakıyordu. Kanlı kefen parçalarıysa binlerce yıllık mumyalara aitmiş gibi yıpranmıştı bir gecede." 9

Dev kurdun ve diğer kurtların roman boyunca adım adım şiddetlenen saldırıları tüm köyün camiye yerleşerek kendilerini korumaya çalışmalarına rağmen devam eder. Sonuçta köyden onlarca insan ölür. Tüm bu süreç boyunca devam eden kar fırtınası kimi köylülerin yardım bulmak için yola koyulduklarında da devam etmiştir. Bu şartlarda onlarca kilometre yürümek zorunda kalan insanlar fiziksel yorgunluk ve soğukla mücadele etmek zorunda kalırlar. Güçleri tükenmeye yakın gördükleri sanrılar ise kafalarının karışmasına, hareketlerini anlamsızlaştırmaya başlamış sonu ölüm de olsa uykuya dalmak istemelerine neden olmuştur. Roman 
pek çok gotik eserde olduğu gibi insanın doğaya ve kendi nesline yönelik kötülüklerinin yine doğa tarafindan cezalandırılışını ve içinde yer aldığı evren karşısındaki güçsüzlügünü vurgulayıp gelenekçi anlayışı olumlayarak, yani, trajik biçimde sona ermiştir.

Ayfer Tunç'un Kar Yolcusu adlı hikâyesi ise dağ başında "gamlı bir lojmanda" "huzursuz ve dar çemberinin içinde yaşamaya devam ede[n]" Eşber adlı bir tren makasçısının saplantılı aşkının ölümle sonuçlanması konu edilir. Dağlar arasında doğal olarak yalıtılmış olan Eşber'in hastalıklı bir yaşam tarzına doğru evrilmesi kaçınılmazdır. En büyük eğlencesinin, gece lojman çevresine gelen kurtlara oyun oynamak, iyice yaklaşmalarını bekleyip ateş etmek olmasının nedeni de budur. Eşber, insanın avcılık zamanlarına doğru evrilmiştir. O, bu tekdüze yaşantısını sürerken Fidan adındaki genç bir kız peşindeki adamlardan kaçarken trenden atlayarak bayılır. Eşber'in onu bulmasıyla saplantılı bir aşk da başlamış olur. Yalnızlık ve insansızlıktan bunalmış olan Eşber bu aşamadan itibaren hikâyenin ölüm, saplantı ve dehşeti temsil eden kişiliği haline gelir. Fidan ise hayatın, mutluluğun ve huzurun birleşimidir. Eşber'in ona yönelik saplantısının ardında elde etmek istediği bu duygular vardır. Eşber'in Fidan'dan vazgeçmek istemeyişi ve hikâyenin sonunda kurtlar tarafindan parçalanışı, yani saplantı ve dehşet Anadolu gotiğinin psikolojik ve somut boyutlarının derinleşmesini sağlayan etkenler olmuştur. Özellikle Edgar Allan Poe ile Amerikan gotiğine yerleşen hastalıklı kişiliklerin metinlerde yer alması normal dışını göstermenin ötesinde insanın iç dünyasının karanlıklarını sergilemek açısından da önemlidir.

\section{3- Şehirden Köye Gidenler}

Anadolu gotiğinin bir başka belirleyeni de kartezyen akıl ile doğaüstünün karşılaşmasının sonuçlarına değinmesidir. Bu türe giren metinlerin büyük kısmında şehirli, okumuş, akılcı değerlendirmeler yapan dolayısıyla doğaüstü güçleri kabul etmeyen kişiler ön plandadır. "Her şeyin bir açıklaması vardır!"10 diyerek karşılaştıkları sıra dışı durumları mantıkla açıklamaya çalışan bu kişiler cadı, hayalet, cin gibi varlıklara inanmazlar. Ancak metnin başındaki bu yaklaşımları aklın yetersiz kaldığı durumlarla karşılaştıklarında değişir ve kabullenme aşamasına varırlar. Bahadır İçel'in Tanrının Üvey Evlatları adlı romanında farklı sosyal kesimlerden gelseler de benzer eğitimden geçmiş insanların şehirdeki olağanüstülüğe dair yorumları birbirine benzemektedir. Kısaca "yeşil" adını verdikleri bir varlığın etkisiyle Kırklareli'ndeki insanların zombiye dönüştüğünü gören okumuş insanlar olayları radyasyon sızıntısı, uzaylılar, salgın hastalık gibi 
nedenlere bağlar. Tüm şehir katliamlarla sarsılırken ve dehşet dalgası her yanı sarmışken insanlıktan çıkmamış olanlar korkuyu akılcı hale getirerek bir çözüm bulunabileceğine yönelik umutlarını canlı tutmaya çalışırlar. Oysa ne bilimsel bir çözüm, ne de dışarıdan gelecek bir yardım söz konusudur. Tek başınalık korkunun gittikçe artmasına neden olmuştur. Romanın sonunda eski insanların Tanrı olarak tanımladığ gizemli gücün kimliğini sadece onu yok etmek için hayatını feda eden Kerem öğrenebilmiştir.

Gerçekte Onlar Hayvan Gibidir adlı hikâyede de yukarıdakilere benzer akılcı, her şeyi bildiğini sanan, köye ve insanların inanışlarına yukarıdan bakan bir hastane memurunun karşılaştığı doğaüstü olaylar anlatılmaktadır. Memur köydeki farklılıkları görmesine rağmen bunları sadece "köyün tuhaflığı" olarak yorumlar. Hayvanlara insan isimleriyle seslenilmesi, imam kılı̆̆ındaki bir adamın Kuran'dan olmadığ belli sözlerle ayinler yapması onun için sadece tuhaftır. Köyde anlatılanlar ise hurafeden ibarettir.

"İnsanların anlattığı hikâyeler ise bütün Anadolu topraklarında anlatılagelen hep aynı türden saçmalıklar. Anlatıla anlatıla artık etkisini kaybetmiş cin çarpması öyküleri, al basmasına tutulmuş zavallı kadınlar, ormanda dolaşan gölgeler, kafası kuzu kafası gibi kocaman olup insan yiyen yılanlar, evliyaların kerametlerine dair öyküler, konuşan yatırlar, Çanakkale Savaşı'ndan beri etrafı kolaçan etmekte olan şehitler, insanları evlerinden kovan hayaletler, fotoğraflara giren korkunç suratlar, tuhaf çocuklar, hayvanlar ve daha neler neler..." 11

Öykünün anlatıcısı akılcı bir insandır. Hurafe denilen inanışlara aldırmaz. Bu yönüyle diğer korku metinlerinde de sıkça rastladığımız modernist aklın temsilcisi olarak somut ve deneysel olmayan her şeyi reddeder. Hikâyenin ilerleyen kısımlarında tanık olduğu ayinde büyüler yapıldığını ve insanların hayvana dönüştüğünü gördüğünde ise tüm akılcı inanç dünyası yıkılır, geriye sadece korku kalır. Açıklayamadığı, doğaüstü bir olaya şahitlik etmiş ve nasıl baş edeceğini bilmediği bir sorunla karşılaşmıştır. Sıradan hayatın ani ve alışkın olunan sınırların dışındaki değişimi korkuyu doğurmaktadır.

Aklın yetersizliği Avrupalı gotik edebiyatın ilk dönemlerinden itibaren ağırlığını korumuştur. Pozitivizmin ortaya çıkışıyla birlikte insan dünyada tek başına, sadece kendi aklı ile başbaşa kalmış, Tanrı ve din duygularının teskin edici etkisi

11 Ayşegül Nergis, "Gerçekte Onlar Hayvan Gibidir”, Anadolu Korku Öyküleri 1, 2. bs., Ankara, Bilgi Yayınevi, 2017, s. 28. 
yok olunca ortaya çıkan terk edilmişlik duygusu ise hiçbir yolla giderilememiştir. Gotik edebiyat içindeki doğaüstünü önceleyen kanat bu eksikliğe cevap vermiştir. Aklın dünyadaki her soruyu cevaplayamayacağ düşüncesinden hareket eden gotik edebiyat, modernist baskıdan bunalan insanın görünmeyen güçlere teslimiyetini meşrulaştırmıştır. Böylece gerçek hayatın güvensizliği yerini iman edilen güçlerin verdiği güvene bırakmıştır. Gotik edebiyatın üç yüz yıldır devam eden küresel modernizme rağmen ayakta kalmasının nedeni budur.

\section{B- Anadolu Vurgusu ve Korkunun Yerli Yüzleriyle Karşılaşma 1- Yerli Kültür}

Anadolu gotiğini korku edebiyatının diğer alt türlerinden ayıran önemli bir özelliği de yerli kültürün eserlerde görünür olmasıdır. Yukarıda da değinildiği gibi yakın döneme kadar yazılan korku eserlerinde Batılı figürlerin ve konuların işlendiği görülmektedir. Örneğin vampir adlı varlık alınarak Batı'dakine benzer biçimlerde kullanılmıştır. Bu sırada yerli kültürde oldukça geniş yer tutan korku unsurları ihmal edilmiştir. İhmal sadece korku ile sınırlı kalmamış, romanın üretildiği toprakların geçmişi ve şimdisi de unutulmuştur. Anadolu gotiği ise bu konuda herhangi bir çekince yaşamadan geçmişten gelen kültürü kullanabilmektedir. Türklerin tarihin derinliklerinden gelen dini, sosyal, edebî tüm kültürel birikimi gotik eserlerde kendilerine yer bulabilmektedir.

Galip Argun'un yazdığı Tan Vakti isimli roman Türk kültürüne çeşitli biçimlerde değinerek yeni dönemin eğilimini sergilemektedir. Romanda Türk isimleri taşıyan vampirlerin 1600 'lerde başlayan hayatlarının 1700 'lü yıllarda devam ettiği görülür. Ancak yerlilik isimlerle sınırlı değildir. Müslüman olan, insan kanı içmeye tövbe edip namaz kılan vampirler İslam kültürünün içerisinde yaşamaktadır. Türk ve İslam tarihinden, Mevlana, Şems, Hayyam, Ferhat ile Şirin gibi isimlerin hayatları ve çeşitli kıssalar romanda Osmanlı dönemi İstanbul'unun kültürel atmosferini yansıtmakta kullanılan motiflerdir. Söz konusu motiflerle yabancı bir kaynaktan gelen vampir figürü okuyucunun çeşitli biçimlerde aşina olduğu bir ortamda canlandırılmıştır. Bu yolla figür ile okuyucu arasındaki uzaklık kapatılmış olmaktadır.

Bir seri katilin anlatıldığı Yılgayak ${ }^{12}$ adlı hikâyede ise çok daha eskiye gidilerek Orta Asya'daki dini anlayış ve gizemli ayinler konu edilmiştir. Türk tarihinin bilinen en eski dönemlerindeki inanışlar, günümüzdeki kötülüklerin cezalandırılmasının aracı haline gelmiştir. Hikâyede Koçağan adlı bereket ayinine hazırlanan kadınlar on iki kişidir ve Karakızlar olarak anılmaktadır. Bu grup

12 Funda Özlem Şeran, "Yılgayak", Anadolu Korku Öyküleri 3, Ankara, Bilgi Yayınevi, 2017. 
iblis diye bildiğimiz Erlik Han'ın kızlarıdır. On iki hayvanlı takvime uygun olarak her biri bir hayvanın kılığına girmiştir. Başlarında ise Umay Ana adlı kadın şaman vardır. Yaptıkları ayinde cinayete kurban gidenleri yer altından çağırıp seri katilden intikam almalarını sağlarlar. Hikâyedeki on iki hayvan figürü, bir çeşit tanrıça olarak bilinen Umay Ana, Türk destanlarında adı çok geçen Erlik Han gibi örnekler eski kültürle kurulan açık bağlantılardır. Bir kısmı sadece yazılı kaynaklarda kalmış olan ve halkın unuttuğu kavramlar hikâyede yeniden ele alınarak canlandırılmıştır. Yazarın bu tercihi yeni konular arayan dönem edebiyatının kapılarının orijinal kaynaklara yönelmesi anlamına gelmektedir. Çok zengin olan Orta Asya mitolojisinin farklı bileşimlerle yeniden kurgulanması tarihi fantezilerde olduğu gibi denenmemiş ancak başarı kazanması muhtemel yeni türlerin yolunu açabilecek mahiyettedir. İlk bakışta sıradan gibi görünen bu tavır aslında son dönemde tüm dünyadaki kültürel evrimle benzerlikler taşımaktadır. Edebiyatta ve sinemada eski destanların farklı coğrafyalara ait mitolojik kaynakların çeşitli biçimlerde kullanıldığı ve çok büyük başarılar kazandığı bu sürece Türk kültürünün de katılması hem yerli edebiyatı hem de küresel kültürel ortamı zenginleştirecek adımlardan biridir.

\section{2- “Tuhaf” İnanışlar, Hurafeler ve Dine Sığınma}

Köy kültürünün belirleyici etkisinin devam ettiği Anadolu'da yöreye göre değişen sayıca fazla ve birbirinden çok farklılaşabilen inanışlara rastlanır. Modernist değerlerin, yaşam biçiminin homojenize etme etkisinin düşük seviyede olduğu köylerde eskiden kalma çok sayıda inanış canlı biçimde var olmaya devam etmektedir. Yerel olan, soyut ve somut her unsurla yoğun bağlantılar kuran Anadolu gotiğinin bu inanışlara da uzak kalmadığı görülür. Söz konusu eserlerde şehirden köye giden kişilerin eğitim, yabancı kültür vs. gibi nedenlerle yabancılaştıkları inanışların bir kısmı dini, bir kısmı ise din dışı alanlarda oluşmuştur. Eserlerde bu inanışlardan en çok cinlerle ilgili olanlarına rastlanmaktadır. Dini kaynaklarda adı sıkça geçen cinlerin görülemeyen, tanık olunamayan varlıkları inançlı insanlar için her zaman korku nedeni olagelmiştir. Dini kaynaklardaki bilgilere ek olarak fiziksel görünümleri, dünyaya etki güçleri, insanların hayatlarına müdahale yöntemleri hakkında zaman içinde halk arasında oluşan spekülasyonlar da cinlerin korku edebiyatında önemli yer edinmesini sağlayan durumlardır.

Şafak Güçlü’nün “İslami korku romanı” olarak tanıtılan Siccin adlı eseri Ege'deki yalıtılmış bir köye musallat olan cinlerin yaptıklarını anlatmaktadır. Şehirden gelen, akılcı Eda'nın ve köylülerin, ormandaki bir kuyudan çıkan cinler tarafından önce çeşitli biçimlerde taciz edilmesi ve ardından dehşet dolu bir katliama maruz kalmaları yerli inanışların romana yansımalarıdır. Cinler tarafından 
yolu kesilip çarpılan Adem'in yaşadıkları ve sonraki görüntüsü cinlerin yeteneklerini tarif etmektedir:

"Tam o anda birden vücudu şiddetle yukarı doğru yükselen Adem, boşlukta bir askıymış gibi kalmış ve hemen akabinde de vücudu şekilden şekile girerek cin çarpmasına maruz kalmıştı.

Tüm kemiklerinin eklem yerlerinden çıkan o iğrenç kemik sesi, taş yolda yankılanıyor ve kulakları sağır eden sese çocukların kahkaha dolu çığlıkları eşlik ediyordu. ... Sol eli bileğinden geriye doğru dönmüş, sağ kolu ise komple bükülmüş ve arkada " $Z$ ” çizer bir şekilde kalmıştı. Bir ayağı kırılmış ve muhtemelen köydeki çıkıkçı tarafından ağaç dallarıyla düz kalabilmesi için çatılmıştı." 13

Cinlerin isterlerse öldürmeden verebildikleri korkunç cezalar onların güçlerini göstermekte, insanları çaresiz bırakacak ölçüdeki bu güçler akılla idrak edilemeyen dünyanın yarattı̆ğ korkuyu perçinlemektedir.

Murat Baykan'ın yazdığ Yaşbaz $^{14}$ adlı öyküde ise cinler tarafindan korunan bir hazineye ilişen dört arkadaşın başlarına gelenlere değinilmektedir. Anadolu'da çok yaygın olan bu inanış, hazinelerin bir türlü bulunamayışının nedeninin halk tarafından açıklanma biçimidir. T11sımlı madalyonun ele geçirilmesinden sonra gelen cin insanların zaman algısını değiştirmekte, her hareketin tekrarlanmasını sağlamaktadır. Ancak cin bununla yetinmez ve bir aileyi yok ederek madalyonu ait olduğu yere götürür. Akılcılığın yetersizliğini vurgulayan korku eserlerindeki "imkânsızlık" yani insani müdahalenin sonuç vermeyeceği düşüncesi eserde hâkim olmuştur.

Benzer inanışlar çok sayıda eserde karşımıza çıkar. Erkut Deral'ın yazdığı Gece Gelinil' ${ }^{15}$ 'nde çok yaygın olan alkarısı konu edilirken bu varlığın çocuklara musallat oluşuna değinilir. Cazı Nene ${ }^{16}$ adlı hikâyede ise cadıların yaşamları ve insanlara kötülükleri anlatılmaktadır. Hikâye cadıların kendi içlerindeki mücadeleye de değinmekte, Karagoncolos Gecesi'nde farklı bölgelerin cadılarının savaşının ayrıntıları verilmektedir.

Görüldüğü gibi bir kısmı başka ülkelerde de var olan ve Anadolu'da da çok bilinen insan dışı varlıklara yönelik inanışların potansiyelinin korku edebiyatını salt yazarın ürettiği kurguların ötesine taşıyabileceği açıktır.

13 Şafak Güçlü, Siccin: Amel Defteri, 3. bs., İstanbul, Hiç Yayınları, 2017, s. 101,104.

14 Murat Baykan, "Yaşbaz", Anadolu Korku Öyküleri 3, Ankara, Bilgi Yayınevi, 2017.

15 Erkut Deral, Gece Gelini, İstanbul, Okuyan Us Yayınları, 2006.

16 Mehmet Berk Yaltırık, “Cazı Nene”, Anadolu Korku Öyküleri 3, Ankara, Bilgi Yayınevi, 2017. 
Korku romanlarının bir kısmında akılcı yöntemlerle mücadele edilemeyen güçlere karşı insanlar dine sığınırlar. Anadolu' da dinin toplumsal hayatın pek çok yönünü etkilediği göz önüne alındığında bu çevreyi anlatan eserlerde dinin de yer alması olağandır. Özellikle cinlerle mücadele edilirken insanların en önemli güvencesi dinî kaynaklar olmaktadır. Orhan Yıldırım'ın Ecinni adlı eserinde Zuhal'in ailesi kendilerine musallat olan cine karşı evin her tarafina ekmek ve Kuran koyarlar. Bu sayede cinlerin içeri girmesini engellerler. Daha sonrasında ise Zuhal ve Arif kendilerini izleyen cinlerden kaçarken camiye sığınırlar. Cinler buraya da giremez. Siccin'de de cinlerin camiye giremedikleri inanc1 tekrar edilir.

Korkut Aldemir'in Reis- $U l$ adlı romanında kendisine kötülük yapan cinlere karşı Nesrin gizemli birinin getirdiği Kuran'dan ayetler okur. ${ }^{17}$ Daha sonrasında ise ayetlerin verdiği güven ve gizemli yardımcı sayesinde intikamını almayı başaracaktır. Galip Dursun'un yazdığı Güzay'ın Bin Dilek Ağacı adlı hikâyede de eskiden olmuş bir olaya değinilir. Kör Raşit adlı bir adam çevresinde gezinen kedi şeklindeki cini görünce Ayet-el Kürsi okur ve cin bir anda kaybolur. ${ }^{18}$

Çalışmamızda değinmediğimiz pek çok eserde karşımıza çıkan dine sığınma insanların en bilindik yöntemleri kullanması anlamına gelmektedir. Eserlerde kötülüğün kaynağı ortaya çıktıktan sonra insanlar bununla mücadele etmenin yollarını araştırırlar. Pozitif düşüncelerle oluşturulan mücadele biçimleri yetersiz kaldığında ya da kimi zaman ilk olarak din akla gelir. Özellikle Kuran insanları somut kötülükten koruyan en önemli silahtır. Kurgulanan olaylar somut kötülügün ötesine de gönderme yapmakta, Kuran'ın genel olarak insanları olumlu, iyi, doğru olana yönlendirdiği düşüncesi de geri planda ifade edilmektedir.

\section{C- Kötülüğğn Sahneye Çıkışı}

\section{Geçmişten Gelen}

Gotik eserlerin başlangıçlarında günlük hayatın sıradan işleyişi anlatılır. Şehirden gelip yerel kültürle tanışan akılcı kişiler çevrelerindeki hayatın "normal" seyrinde sürdügünü düşünürler. Ancak ilerleyen zamanla birlikte garipliklerin farkına varırlar, sonrasında da kötülükle yüz yüze gelirler. Kötülük kimi eserlerde geçmişten gelen bir lanet olarak tasvir edilir. Doğaüstü kimi güçler geçmişte yaptıkları kötülüğü tekrarlamak üzere geri gelir ve insanların onlarla mücadelesi yeniden başlar. Siccin romanında katliam yapan cinler aynı şeyi elli yıl önce de gerçekleştirmiştir. Tanık oldukları katliamın tekrarlanacağı ihtimali köylülerin korkusunu daha da arttırmıştır.

17 Korkut Aldemir, Reis-Ul, Ankara, Trend Yayınevi, 2015, s. 157

18 Galip Dursun, “Güzay’ın Bin Dilek Ağacı”, Anadolu Korku Öyküleri 1, 2. bs., Ankara, Bilgi Yayınevi, 2017, s. 165. 
Tanrının Üvey Evlatları adlı romanda da "Yeşil" adı verilen gizemli varlığın Roma döneminden başlayarak Osmanlı ve günümüz Türkiye'sine kadar uzanan zaman diliminde insanları zombiye dönüştürüp kullanması anlatılmaktadır. "Yeşil” eski insanların tabiat Tanrısı olarak taptığı ancak ne olduğu tam bilinmeyen bir varlıktır. Bir ağaç kovuğunda binlerce yıldır varlığını sürdürmektedir. Kendisini bulan birkaç insanı etkiledikten sonra o insanların başkalarına aktardıkları tohumlarla kitlesini genişletmektedir. Diğer insanlar ise kimi zaman geçmişten edinilen bilgi kırıntıları kimi zaman kendi deneyimleriyle onunla mücadele etmeye çalışmaktadır. Ancak yaratığın ne olduğunun ve gerçek gücünün sınırları bilinmediği için söz konusu deneyimleri yüzyıllar boyunca binlerce insanın hayatına mal olmuştur. Romandaki varlığın kendi isminin olmayışı insanların onun hakkında konuşabilmek için isim vermelerine yol açmıştır. Gotik eserlerin bir kısmında bu türden isimsiz varlıklar konu edilirken bazıları da geçmişten gelen isimlerle anılır. Anadolu'da özel durumlar için yerleşik olan isimler burada da karşımıza çıkar. Örneğin yaşlı, insanlara musallat olan kadınlar cadı, karakura gibi isimler alır. Ayrıca alarcın, alkarısı, peri, iblis, hortlak, hayalet gibi isimler de kötülüğün kaynağı için verilmiş ve eserlerde rastlanan isimlerdir.

\section{2- Rüyalar, Sanrılar}

Kötülük sahneye çıktığında insanların günlük rutini de değişmeye başlar. Özellikle geceleri insanları rahatsız eden ya da öldüren kötücül varlıkların etkisi gündüzleri de devam eder. Bunu göstermek için rüyalar ve sanrılar çok işlevsel görünmektedir. Kayahan Demir'in Kefensizler Mezarliğ adlı eserinde sanrılar geniş biçimde kullanılmıştır. Urfa'daki ailesinden kalan eve giden Yıldırım ve ailesinin başına gelenler Anadolu gotiğinin değindiğimiz tipik özellikleri eşliğinde anlatılırken mezarlık, kuzgun, sis, iskeletler gibi çok sayıda korku unsurunun yanı sıra evde ve dışarıda gerçekleşen gizemli olaylar da bu atmosferin pekişmesini sağlamaktadır. Eserde sık sık mezarlığın etkisinde kalan Yıldırım'ın sanrılarına değinilir. Gerçekle zihnindeki hayali ayırt edemez hale gelen Yıldırım bir süre sonra eski, yıkılmış olan rasathaneyi yeni yapılmış gibi görmeye başlar. Kendisi de astronom olan Yıldırım daha da ileri giderek orada bazı astronomik gözlemler yapmaya girişir. Gerçek hayattan kopmaya başlaması ise başlı başına korkutucudur. Gerçeklik sınırlarının belirsizleşmesi, bilinen dünya ile ilgisi olmayan bir başkasından gelen varlıkların, olayların hatta yaşamların bu sınırları aşması modern insanın kafasındaki netliği yok edecek bir etkiye sahiptir. Akılla yorumlanamayan, bilimsel tekniklerle çözümlenemeyen her şeyin potansiyel tehlikesi insanın gerçek dünyaya yönelik güvenini yok etmekte ve korkutmaktadır. Dolayısıyla sanrılar ve günlük hayatı etkileyen kâbuslar, korku eserlerinin vazgeçilmezlerindendir. 
Cevizin Gölgesi Hain Olur ${ }^{19}$ adlı hikâyede ise Kadir adlı çobanın yıllar önce ölen Leyla adındaki çocukluk aşkını görmesi ve sonrasında gelişen olaylar anlatılır. Hep aynı tepede ve ceviz ağacının altında gerçekleşen olaylar ilk başta Kadir'in uyurken gördüğü rüyalarla başlar. Ancak zamanla Kadir' in rüyaları sanrıya dönüşür ve uyanıkken de sevdiğini görmeye başlar. Ancak bu olayda sanrılara yol açan kimliği belirsiz bir varlıktır. Onu musallat olan varlıktan kurtarmak isteyen Hüseyin Usta'nın eşi Kuran okur. Kadir geçici bir süre iyileşir ancak sonrasında sanrılar yine başlar ve onun ölümüne neden olur. Hikâyede somut hiçbir eylem, yaratığın herhangi bir müdahalesi olmamasına karşın sanrıların onun tüm düşüncelerini ele geçirmesi tehlikeyi yaratan bir durumdur. Bir başka deyişle kötücül olan fiziksel bir eyleme girişmese de insanlara büyük zarar verebilmektedir.

Rüya ve sanrılar Beyaz Çöl, Ağlatan, Siccin gibi romanlar yanında Gelin $\mathrm{Otu}^{20}$, Hasat ${ }^{21}$, Bir Garip Adam ${ }^{22}$ gibi çok sayıda hikâyede de gerilimin arttırılması, kötücül olanın etkisinin giderek derinleştiğinin gösterilmesi, çaresizliğin vurgulanması gibi amaçlarla defalarca kullanılmıştır. Rüya ve sanrılar, kötülük karşısında insanın iç dünyasının nasıl şekillendiğini göstermeleri nedeniyle gotik edebiyat için kullanışlı motiflerdir.

\section{3- Dehşet: Ölüm, Tecavüz, Kan}

Gotik edebiyat psikoloji ağırlıklı gerilim duygusunun yanında fiziksel terörü de kullanarak okuyucusunu sarsmaya çalışır. İnsanların çeşitli biçimlerde öldürülmelerinin ötesinde öldürme eyleminin sarsıcı oluşu da etkiyi arttıracaktır. Bunun için tecavüzden ceset parçalamaya çok geniş bir skalada fiziksel saldırılar kurgulanır. Tüm korkuların nihai noktası kanın akması ve ölüme doğru gidişte hissedilen duygulardır. Geri dönülemeyecek noktaya ulaşmak ve yaşamla ilgili tüm umudun yitmesi her şeyin sonudur. Dolayısıyla bu zirvenin tasviri eserin etkisini de büyük ölçüde etkilemektedir.

Konuşmayanlar $^{23}$ adlı öyküde Yeltepe köyü sakinlerinden üç kızın öldüğü olaylara değinilir ve Gülcan'ın ölümü ayrıntılı anlatılır. Köylüleri etkisi altına alan yaratık nedeniyle babası ve kuzenleri tarafindan tecavüze uğrayan Gülcan

19 Kayra Küpçü, “Cevizin Gölgesi Hain Olur”, Anadolu Korku Öyküleri 1, 2. bs., Ankara, Bilgi Yayınevi, 2017.

20 Iş11 Beril Tetik, “Gelin Otu”, Anadolu Korku Öyküleri 1, 2. bs., Ankara, Bilgi Yayınevi, 2017.

21 Orkide Ünsür, "Hasat”, Anadolu Korku Öyküleri 3, Ankara, Bilgi Yayınevi, 2017.

22 Kenan Hulusi Koray, Kenan Hulusi Koray'dan Hikayeler, haz. İnci Enginün, Ankara, Kültür ve Turizm Bakanlığı Yayınları, 1983.

23 Umut Dülger, "Konuşmayanlar", Anadolu Korku Öyküleri 2, 2. bs., Ankara, Bilgi Yayınevi, 2017, s. 13. 
daha sonra bir tepede terkedilir. Kötücül varlık da gelip onu parçalayarak öldürür. Burada tecavüz sahnesi kendi başına dehşet vericidir. Çok sayıda akraba erkeğin yaptığ 1 kötülük zaten delirtici bir etkiye sahiptir. Ancak şiddet bununla sınırlı kalmamıştır. Tepede Gülcan'ın vücudunun çeşitli yerlerinden kanların fışkırması, vücudunun kan gölü içinde kalması okuyucuya aktarılmak istenen etkinin dozunu arttırmaktadir.

Gölgeler ${ }^{24}$ adlı hikâyede ise tekinsiz görünümdeki bir kasabaya atanan coğrafya öğretmeninin tanık olduğu insanlık dişı manzaralar tasvir edilmektedir. Kasabalıların akşamları seyrine koştukları oyun öğretmenin de merakını çeker. Kasabalıların davetiyle onlarla giden öğretmen oyunun adının Acıvar ile Karagün olduğunu öğrenir. Karagün, Acıvar'ı öldürdüğünde oyun biter. Öğretmenin şahit olduğu bu sıra dışı manzara son değildir. Dehşet artarak devam edecektir. Bir başka oyunda seksen insan cesedinin birbirine zımbalanmış, dikilmiş parçalarının sahnede kukla gibi oynatıldığını görür. Öldüğü için savunmasız hale gelen insanların mezara konulmak yerine yaşayanlar için zevk nesnesi haline gelmeleri tüm kültürlerde lanetlenen bir davranıştır. Hikâye kişisinin ve okuyucunun, bildikleri dünyanın tüm insanî değerlerinin sarsıldığ 1 süreç öyküde yaratılmak istenen etkinin en yoğun anını oluşturmaktadır.

Beyaz İntikam'da köylülerin boyunlarının orakla parçalanması, Ecinni'de bir baykuşun boynunun kırılması ve ağaca çarpılarak parçalanması, Çoruh Seni Lanetliyor'da yaşlı kadınların öldürüldükten sonra cesetlerine tecavüz edilmesi gibi sahneler okuyucunun kendi güvenli dünyasında hissedemediği dehşet duygusunu yaratmaya yöneliktir. Modern dünyada, doğanın her türlü tehdidinden uzak yaşayan akılcı insanın bastırdığ 1 gerilim, hareket ve heyecan ihtiyacı bu şekilde karşılanabilecektir. Böylece günlük hayatın monotonluğunun aşılması ve dünyanın akılcı sisteminin dışına çıkılması hedeflenmektedir. Gotik edebiyatın modernizm sürecine yönelik tepkisel, muhalif tavrı sıra dışı şiddet sahneleriyle gotik edebiyatta devam etmektedir.

\section{4- Törenler, Ayinler ve Direniş}

Kötülük temelde bireysel bir eylemdir. Çok sayıda kişinin yaptığı kötü bir eyleme katılmak bile bireysel bir tercihin sonucudur. Ancak bireysel kötülüğün toplumsal meşruiyet kazanması, kötücül bireyin eylemlerinin olumlanlaması ancak törensel eylemler ve ayinler ile gerçekleşir. Ayinler aracıllğıyla elde edilen meşruiyet bireyin vicdan azabı çekip kötülükten vazgeçmesinin önünde engeldir.

24 Murat Başekim, “Gölgeler”, Anadolu Korku Öyküleri 3, Ankara, Bilgi Yayınevi, 2017. 
Toplum tarafindan kutsanan eylemin sonraki nesiller tarafından da devam ettirilmesi ancak bu törenler sayesinde mümkün olabilecektir.

Anadolu gotiğinin pek çok örneğinde rastlanan ayinler kötülüğün toplum içinde yerleşik hale gelmesini sağlayan olaylardır. Kuyu adlı öyküde Anşa'nın lanetinden kurtulmak isteyen köylüler Topraktandoğan'ın yönlendirmesiyle yine Anşa'nın kızı Güles'i kuyu başında kurban etmeye karar verirler. Herkes bireysel olarak bu canice hareketten çekinmekte, vicdan azabı duymaktadır. Ancak tüm köyün katıldığı ayin sayesinde Zeynep adındaki köylü, kızın başını kesme cesaretini kendinde bulur. Tek başına işlenemeyecek cinayet toplumsal onay sayesinde gerçekleştirilmiştir.

Gelin Otu adlı öyküde de alkarısının Deniz adındaki hamile kadını ele geçirme çabalarının gelincik tarlasında başarıya ulaşmasına kadar olan süreç anlatılır. Ancak alkarısı eylemlerinde yalnız değildir. Onun kötücül çabası gelincik tarlasının etrafını saran köylülerin törensel bir havada verdikleri sessiz onay ile desteklenmektedir.

Gerçekte Onlar Hayvan Gibidir, Konuşmayanlar, Yılgayak gibi öykülerde de anlatılan ayinler küçük toplumsal grupları saran kötücül karakterin tezahür etme biçimlerini sergilerken kimi eserlerde ise tersi yani toplumun kötülükle mücadelesi üzerinde durulur. Sözü edilecek olan bu eserlerde ise kötülük bireyin gücünün çok üzerindedir. Ayrıca sadece bir kişiyi hedef almamakta yerel grubun tamamına musallat olmaktadır. Sonuçta kötülük ancak dayanışma ve güç birliği ile yenilebilecektir. Gruptakilerin her biri kendi katkılarını sunarak mücadeleye katılır: İmam dua okur; güçlü erkekler savaşır; kadınlar, çocuklara göz kulak olur, vs.

Fırtınalar Takvimi adlı öyküde Süfyan adlı cinin ordularıla köye saldırmas1 ve Çolpan adlı yarı insan yarı peri varlığın onlarla mücadelesi anlatılır. Çolpan, düşmanın tüm köyü yok edebilecek güçte olduğunu bildiğinden köylüleri psikolojik baskı ile bu savaşa dâhil eder. Kulübelere sığınan köylüler cinlerin içeri girmesine direnerek hayatta kalmaya çalışır. Tek başına hiçbiri cinlere karş1 koyacak güçte değilken birlik olarak cinleri savuştururlar.

Kötülüğe karşı toplu direniş̧in en etkileyici ve destansı anlatımına Beyaz Çöl adlı romanda rastlanmaktadır. Önceleri birbirinden kopuk olarak farklı yerlerde (mezarlık, köy, köy dışı) kurtlarla savaşan köylüler büyük kurdun yarattığ1 dehşeti görünce birlik olmaya karar verirler ve camiye sığınırlar. Burada kurdun en dehşetli saldırıları sırasında birbirlerini koruyarak, yaralarını sararak ayakta kalmaya çalışırlar. Aralarından çok sayıda kişi öldürüldüğünde cenazelerin kaldırılması, caminin tahkim edilmesi, kurdun püskürtülmesi gibi işlerde işbirlikleri devam eder. 
Toplumsal işbirliği ile kötülüğün alt edilmesinin metaforik anlamları da olduğu unutulmamalıdır. Yerel bir gruba saldıran yabancı varlık dışarıdan gelip yerleşik düzeni bozmaya ve insanların hayat dâhil her şeyini elinden almaya çalışmaktadır. Onunla mücadele sadece bir şeyleri kurtarma anlamına gelmemektedir. $\mathrm{Bu}$ mücadele birlik ruhunu ve grubun kimliğini pekiştirmeye katkıda bulunmaktadır. "Biz ve öteki”"nin karşılaşması kısa vadede "biz”e zarar verirken uzun vadede onun bir arada kalmasını sağlar.

\section{Sonuç}

Korku edebiyatı popüler romanın diğer türleri gibi her geçen gün gelişmektedir. Bu süreçte polisiye, fantastik gibi türlerden ve farklı diğer alt türlerden kimi esinlenmeler doğaldır. Önemli olan başka bir türden alınan malzemenin orijinal kurgu ve tema ile yeniden şekillendirilmesidir. Örneğin gotik ya da fantastik edebiyattan alınan bir varlığın yerli kültür hazinesi de katılarak işlenmesi zaman içerisinde tekdüzeleşmiş bir temanın yenilenmesinin yolunu açacaktır. Söz gelimi Batılı gotik edebiyattan alınan hayaletlerin Anadolu'daki kültürel ortama uyarlanması binlerce kez anlatılan hayalet öykülerinin yenilenmesinin yolunu açacaktır. Bu noktada Anadolu gotiği adını verdiğimiz alt tür devreye girmektedir. Anadolu'daki çok farklı kültürel sahalardan gelen çok sayıdaki farklı inanış ve yaşam biçimleri korku edebiyatına kaynaklık ettiğinde kültür endüstrisinin sıradanlaşmış imajlarının yenilenmesi mümkün olacaktır.

Anadolu barındırdığı inanç zenginliğinin yanında coğrafyası ile de hem geleneksel gotik hem de modern korku eserleri için zengin bir sahne olma potansiyeli taşımaktadır. Şimdiye kadar kaleme alınmış olan korku eserlerindeki İstanbul merkezlilik bu türün gelişmesi yerine geri kalmasına yol açmıştır. Batılı eserlerden çok da farklı olmayan kişi kadrosu ve mekânlarıyla yenilikten çok tekrarlara neden olmuştur. Oysa yenilik yerli kültürün ve Anadolu coğrafyasının işlenmesiyle sağlanabilecektir.

Son dönem korku romanlarına baktığımızda sözünü ettiğimiz yerliliğin yoğun, kendi kültüründen çekinmeden biçimde işlendiği göze çarpar. Olağanüstülük içersin ya da içermesin bu dönemin korku edebiyatı Anadolu'daki yaşam biçiminden, geçmişten getirilmiş olan kültürden, dini yaşamdan, modernist anlamda geri kalmışlıktan utanmadan bunları edebiyatın malzemesi haline getirmektedir. Korku edebiyatının gelişimi için elzem olan söz konusu yönelim özellikle halk edebiyatı çalışmalarının daha derinlikli incelenmesiyle sonsuz denecek ölçüde gelişme potansiyeli taşımaktadır. Anadolu'nun derinliklerine doğru yol alan bu tavır şu andaki haliyle bile İstanbul'un edebiyattaki dayanılmaz ağırlığını aşmış ve taşrayı merkeze taşımış, yok sayılanı herkesin görebileceği biçimde sergilemeye başlamıştır. 


\section{Kaynakça}

Anadolu Korku Öyküleri 1, 2. bs., Ankara, Bilgi Yayınevi, 2017.

Anadolu Korku Öyküleri 2, 2. bs., Ankara, Bilgi Yayınevi, 2017.

Anadolu Korku Öyküleri 3 Yılgayak, Ankara, Bilgi Yayınevi, 2017.

Aldemir, Korkut, Reis-Ul, Ankara, Trend Yayınevi, 2015.

Argun, Galip, Tan Vakti, İstanbul, Parşömen Yayınları, 2011.

Çelik, Erol, Ağlatan, İstanbul, Avrupa Yakası Yayıncılık, 2014.

Demir, Kayahan, Kefensizler Mezarlı̆̆ı, 3. bs., İstanbul, Carpe Diem Kitap, 2018.

Deral, Erkut, Gece Gelini, İstanbul, Okuyan Us Yayınları, 2006.

Dikenelli, Çağan, Taşıyıcı, İstanbul, +1 Kitap, 2005.

Faflak, Joel - Haslam, Jason William, (haz.), American Gothic Culture: An Edinburg Companion Ed., Edinburg, Edinburgh University Press, 2018.

Güçlü, Şafak, Siccin: Amel Defteri, 3. bs., İstanbul, Hiç Yayınları, 2017.

İçel, Bahadır, Tanrının Üvey Evlatları, İstanbul, Altın Bilek Yayınları, 2014.

Kenan Hulusi Koray, Kenan Hulusi Koray'dan Hikayeler, haz. İnci Enginün, Ankara, Kültür ve Turizm Bakanlığı Yayınları, 1983.

Mull, Çiğdem Pala, Gotik Romanın Kıtalararası Serüveni, Ankara, Ürün Yay1nlar1, 2008.

Öztürk, Aydın Şahin, Beyaz Çöl, Ankara, Ihlamur Kitap, 2012.

Savoy, Eric - Martin, Robert K. (haz.), American Gothic: New Intervations in a National Narrative, Iowa, University of Iowa Press, 1998.

Smith, Allan Lloyd, American Gothic Fiction: An Introduction, New York, London, Continuum International Publishing, 2005.

Turner, Glenn, "The Branching of 19th Century American Gothic Literature from its European Roots", http://forumonpublicpolicy.com/wp-content/uploads/2016/12/Turner.pdf (erişim: 27.05.2019)

Varol, Kemal, (haz.), Demiryolu Öyküleri, İstanbul, Sel Yayıncılık, 2010.

Yıldırım, Orhan, Ecinni: Aykırı Dünyayla İlişkiler, İstanbul, IQ Kültür Sanat Yayınc1lik, 2003. 
, Beyaz Intikam, İstanbul, IQ Kültür Sanat Yayınc1lık, 2005. , Çoruh Seni Lanetliyor: Bir Katilin Anatomisi, İstanbul, IQ Kültür Sanat Yayınc1lık, 2004. 